\title{
THE ORIOLE RETURNS
}

PHMUS BORDASS, Box 313, Fort Qu'Appelle, SK SOG 1 SO

On 19 May, the first oriole returns. I immediately filled the feeder and hung it out on a nearby tree. Soon there was one male and four females. The male dipped at the nectar a bit, but it seemed as though the females didn't know what it was. Then I remembered what Al Smith at the Last Mountain Bird Observatory said. He told us orioles like slices of orange. I cut one into slices and tacked it to the tree. It didn't take them long to find it and demolish all slices. The nectar feeder was ignored. I. cut another orange and expanded the station to two trees. Now there were four females and four males, all squabbling over the oranges. I put more slices on two trees at the front by the street and as I replaced the slices the orioles dropped the rinds on the ground at the foot of the tree. By late afternoon, six oranges later, there were fourteen orioles flashing around. What a fantastic sight! At the same time the backyard was moving with about ten male goldfinches, and some females, a flock of Pine Siskins, all at the niger feeder. There were four Rose-breasted Grosbeaks, two males and two females at the sunflower seeds.

On Saturday, 24 May, at 8:00 a.m. there was a male Western Tanager on the tree. I immediately phoned Lorne Rowell, and Ron Hooper. Lorne, having the shorter distance, made it in time to see it, but by the time Ron got here the bird had disappeared and we didn't see it again. Ron extracted a promise from me that if I saw it again, I was to phone him. That same evening there was another bird at the oranges. I was sure it was a female tanager, but it wasn't yellow as illustrated in the field guides. Rather, it was a muted olive and grey but had the structure of the tanager. The orioles kept chasing it away. Sunday morning, 25 May, 6:30 a.m. it was there again, so I dutifully phoned Ron. When he got here he confirmed it as a female tanager. This is only the second record according to Manley Callin's book for southern Saskatchewan.

It stayed around for three or four days. By then most of the orioles had moved on to continue their trip to their destinations.

Estimates indicate an American Kestrel eats almost 300 mice a year.

A hawk's eye has 7.5 times as many visual cells as a human.

The peregrine's may prey was the Passenger Pigeon; when the pigeon became extinct, the Peregrine population dropped too. 